\title{
Isolation, Characterization, and Identification of Biological Control Agent for Potato Soft Rot in Bangladesh
}

\author{
M. M. Rahman, ${ }^{1}$ M. E. Ali, ${ }^{2}$ A. A. Khan, ${ }^{1}$ A. M. Akanda, ${ }^{1}$ Md. Kamal Uddin, ${ }^{3}$ \\ U. Hashim, ${ }^{4}$ and S. B. Abd Hamid ${ }^{2}$ \\ ${ }^{1}$ Department of Plant Pathology, Bangabadhu Sheikh Mujibur Rahman Agricultural University, Gazipur 1706, Bangladesh \\ ${ }^{2}$ Nanotechnology and Catalysis Research Center, Universiti Malaya, 50603 Kuala Lumpur, Malaysia \\ ${ }^{3}$ Institute of Tropical Agriculture, Faculty of Agriculture, Universiti Putra Malaysia, 43400 Serdang, Malaysia \\ ${ }^{4}$ Institute of Nano Electronic Engineering, Universiti Malaysia Perlis, 01000 Kangar, Malaysia \\ Correspondence should be addressed to M. E. Ali, eaqubali@gmail.com
}

Received 8 January 2012; Accepted 12 February 2012

Academic Editors: F. J. de Bruijn, J.-F. Hausman, and D. Zhou

Copyright () 2012 M. M. Rahman et al. This is an open access article distributed under the Creative Commons Attribution License, which permits unrestricted use, distribution, and reproduction in any medium, provided the original work is properly cited.

\begin{abstract}
A total of 91 isolates of probable antagonistic bacteria of potato soft rot bacterium Erwinia carotovora subsp. carotovora (Ecc) were extracted from rhizospheres and endophytes of various crop plants, different soil varieties, and atmospheres in the potato farming areas of Bangladesh. Antibacterial activity of the isolated probable antagonistic bacteria was tested in vitro against the previously identified most common and most virulent soft rot causing bacterial strain Ecc P-138. Only two isolates E-45 and E-65 significantly inhibited the in vitro growth of Ecc P-138. Physiological, biochemical, and carbon source utilization tests identified isolate E-65 as a member of the genus Bacillus and the isolate E- 45 as Lactobacillus sp. The stronger antagonistic activity against Ecc P-138 was found in E-65 in vitro screening and storage potatoes. E-65 reduced the soft rot infection to 22-week storage potatoes of different varieties by 32.5-62.5\% in model experiment, demonstrating its strong potential to be used as an effective biological control agent for the major pectolytic bacteria Ecc. The highest (62.5\%) antagonistic effect of E-65 was observed in the Granola and the lowest $(32.7 \%)$ of that was found in the Cardinal varieties of the Bangladeshi potatoes. The findings suggest that isolate E-65 could be exploited as a biocontrol agent for potato tubers.
\end{abstract}

\section{Introduction}

Bacterial soft rot is one of the major postharvest diseases of potato (Solanum tuberosum), the fourth major food crop of the world after rice (Oryza sativa), maize (Zea mays), and wheat (Triticum aestivum) [1]. It is the third major food crop of Bangladesh after rice and wheat. Approximately 22\% of potatoes are lost per year due to viral, bacterial, fungal, and pest attack to potato tuber and potato plant, incurring an annual loss of over 65 million tones and bacterial soft rot alone accounts for $30-50 \%$ of this huge loss [1]. The effect of the disease is more pronounced in the countries where appropriate storage facilities are lacking or inadequate. Control of bacterial soft rot of vegetables is traditionally based on phytosanitary and cultural practices [2]. Use of chemicals is generally not recommended to control soft rot
[2] because of the high risk of the residual effect of toxic chemicals that might be hazardous to consumers' health.

Biological control is a potential method to control soft rot disease [3]. The strategy for biological control of plant diseases involves the use of antagonistic microorganisms before or after the infection takes place. Commercial biological control agents are available for the seed treatments and soil amendments to protect the plants against soil borne pathogens. Currently, the bacteria Bacillus subtilis and Pseudomonas spp. and the fungi Gliocladium virens and Trichoderma spp. are the organisms mostly used for biological control strategies. Potentiality of biological control of bacterial soft rot with antagonistic bacteria or with growth promoting rhizobacteria, fluorescent pseudomonads, and endophytic bacteria in many crops has already been proven [2-5]. Potatoes could be treated with bacteria, originally 
selected from potato surfaces, which are inhibitory to the growth of E. carotovora. Fluorescent pseudomonads are attractive candidates for biological control of E. carotovora because they colonize the potato rhizosplane and rhizosphere and produce high populations [6-9] and they produce a variety of secondary metabolites and substances that can alter the composition of the rhizosphere microflora [10, 11]. Suppression of soft rot bacteria was attributed to the production of fluorescent siderophores that were essential for uptake of iron by the pseudomonads [12]. The bioagent B. subtilis was the most effective in reducing the soft rot decaying stored potato tubers [13].

The importance of environment friendly plant protection methods is greatly emphasized in the sustainable agriculture. The recent increase in publication on bacterial endophytes reflects an interest in their potential benefits as biocontrol agents in agriculture [14]. So the development of suitable and environment friendly control measures against soft rot causing bacteria may minimize the loss in storage and improve the quality of potato. In Bangladesh, suitable measures to control soft rot of potato are yet to be developed. As the performance of an antagonistic bacterium is dependent on environment, the identification of a suitable bacterial strain which has appropriate antagonistic properties to the common potato soft rot of Bangladesh should play a significant role to develop an environmentally friendly biological control measure to prevent potato damage in Bangladesh. Considering the above facts, we extensively searched for an effective biological control agent for the most common potato soft rot strain Ecc P-138 of Bangladesh. The antagonistic activity against soft rot of potato strain Ecc P138 was tested in in vitro and storage experiments, and the strain identification was performed through physiological and biochemical identification schemes.

\section{Experimental Section}

2.1. Isolation of Bacteria Antagonistic to Soft Rot Ecc P-138. As a potential source of antagonistic bacteria of potato soft rot Ecc, rhizospheres and endophytes of different crop plants as well soils and atmosphere of major potato farming areas in Bangladesh were selected. For the isolation of rhizospheric bacteria, soil samples were collected from rhizosphere of potato, onion, papaya, rice, tomato, garlic, zinger, and turmeric. Dilution plate techniques were followed, and yeast peptone dextrose agar (YPDA) was used as a basic medium. Ten gram ( $10 \mathrm{~g})$ of soil was taken from each rhizosphere soil samples in a beaker and was mixed thoroughly in $100 \mathrm{~mL}$ distilled water on a rotary shaker $(250 \mathrm{rpm})$. Then, the suspension was allowed to settle down to soil for $10 \mathrm{~min}$. After sedimentation, the soil suspension was taken from the upper part and diluted to $10^{3}-10^{4} \mathrm{x}$ in distilled water. The diluted soil suspension was streaked on petri dishes containing YPDA and incubated at room temperature for 24-48 h. At the end of the incubation, different types of bacterial colonies that appeared on the medium were selected and restreaked for pure culture. The pure culture of selected bacterial isolates was preserved in test tubes containing sterilized water for antibacterial evaluation.
To isolate endophytic bacteria, fresh and diseased plant specimens of root, stem, and leaves of various plants including potatoes and onions were collected from different locations of Bangladesh. Desired bacteria were isolated following streak-plate technique using the medium YPDA. After 24$48 \mathrm{~h}$ of incubation, bacterial colonies were observed on the medium. Isolated bacterial colonies were restreaked on YPDA media for obtaining pure culture. Colonies selected from isolated plates were transferred into test tubes containing $5 \mathrm{~mL}$ sterilized distilled water. The tubes with the bacterial suspension were preserved at room temperature.

Some bacterial isolates were isolated from soil mixed with compost following the procedures as described in case of rhizospheric bacteria. Several bacteria were isolated from atmosphere following air trapping. Three petri dishes containing YPDA were placed in the field and also in the laboratory of Bangabandhu Sheikh Mujibor Rahman University (BSMRAU) and were kept for 5, 10, and $15 \mathrm{~min}$. The petri dishes were covered with the lids and incubated at room temperature for $24-48 \mathrm{~h}$. The bacterial colonies developed on the medium were restreaked for pure culture and preserved in test tubes containing sterilized distilled water.

2.2. Antagonistic Activity Test. Antagonistic activity of the bacterial isolates was tested in vitro using plate chloroform method $[15,16]$. Briefly, one loop full of 1-2-day-old probable antagonistic bacterial colony grown in YPDA medium was transferred to the center of a petri dish containing $20 \mathrm{~mL}$ of YPDA. The plates were incubated at $30^{\circ} \mathrm{C}$ for 2 to 3 days. When the bacteria colonies were formed as several millimeters in diameter, the plate was turned upside down. A sheet of filter paper was placed in the petri dish lid with $0.5 \mathrm{~mL}$ of chloroform. The dish was kept at room temperature for $2 \mathrm{~h}$. After complete evaporation of chloroform vapor, $5 \mathrm{~mL}$ suspension of indicator bacteria (ca. $10^{8} \mathrm{cfu} / \mathrm{mL}$ ) was overlaid on each plate. Here, the soft rot bacterial strain, E. carotovora subsp. carotovora (Ecc) P-138, was used as an indicator bacterium. The plate thus prepared was incubated at $30^{\circ} \mathrm{C}$ for 2 days. When an inhibition zone appeared, its diameter was measured to evaluate the antibacterial activity of the probable antagonistic bacteria [16]. The bacterial isolates which showed antagonistic effect against indicator bacteria were selected for the further studies.

\subsection{Biological Control of Soft Rot Disease under Storage} Conditions. To evaluate the effectiveness of the selected antagonistic bacteria in reducing soft rot infection in storage potatoes, $700 \mathrm{~g}$ of fresh tubers of each three potato varieties, Cardinal, Diamant, and Granola, were dipped in suspensions of antagonistic bacterium E-65 (ca. of $10^{7}-10^{8} \mathrm{cfu} / \mathrm{mL}$ ), for $30 \mathrm{~min}$ and air-dried separately. The treated potato tubers were inoculated with soft rot bacteria E. carotovora subsp. carotovora $\mathrm{P}-138$ by spraying with inoculum suspensions $\left(10^{7}-10^{8} \mathrm{cfu} / \mathrm{mL}\right)$ with an atomizer. Inoculated potato tubers bulbs were air-dried and stored separately in net bags at room temperature. Data on soft rot incidence was recorded after $2,6,10,14,18$, and 22 weeks of inoculation. Number and weight of soft rot infected tubers were recorded 
and expressed in percentage using the following formula described by Abd- El-Khair and Karima [13]:

Infection $\%$

$$
=\frac{\text { number of infected tubers }}{\text { Total number of tubers }} \times 100 \text {, }
$$

Loss of weight $\%$

$=\frac{\text { Initial weight }- \text { weight after discarding the infected sample }}{\text { Initial weight }}$

$\times 100$.

Percentage of disease reduction (PDR) was calculated according to the following formula described by Hajhamed et al. [17]:

$$
\mathrm{PDR}=\frac{\text { Ack }- \text { Atr }}{\text { Ack }} \times 100,
$$

where Ack and Atr represent the severity of the disease in control and treated specimens, respectively.

\subsection{Characterization and Identification of Antagonistic Bac-} terial Strains. Preliminary characterization of the selected antagonistic bacterial isolates was performed by a series of physiological and biochemical tests as described earlier. The tests were potato soft rot [18], gram reaction [19], growth at $37^{\circ} \mathrm{C}$, growth in $5 \% \mathrm{NaCl}[20,21]$ catalase production [22], oxidase reaction [23], nitrate reduction [22], methyl red test [21], arginine utilization test [24], gas formation test [25], levan formation test [26], and tobacco hypersensitivity reaction (HR) test [27]. Carbon source utilization tests were performed using Ayer's media [28].

\section{Results}

3.1. Antagonistic Test. Out of 91 probable antagonistic bacterial isolates, 28 isolates were extracted from rhizosphere soil of nine crops: potato, onion, papaya, rice, tomato, garlic, zinger, and turmeric collected from Rangpur, BSMRAU, and Bangladesh Agricultural Research Institute (BARI) located at Gazipur. The 44 endophytic bacterial isolates were obtained from 13 plant varieties; 4 isolates were from compost fertilizers, 3 isolates were from atmosphere, and 12 isolates were from microbiology laboratory of BSMRAU. The host, host organs, locations and time of isolation, media used for isolation, and colony characters are shown in Tables 16 (See Supplementary Information available online at doi: $10.1100 / 2012 / 723293)$.

3.2. Selection of Antagonistic Strain of the Most Common Potato Soft Rot Bacterium. Among the 91 bacterial isolates tested for antagonistic activity, only 2 of them (isolates E65 and E-45) demonstrated significant antagonistic effects against the indicator soft rot Ecc P-138 (Tables 1-6). Isolates E-45 and E-65 were extracted from the endophytes of papaya and potato. These bacterial isolates produced distinct inhibition zones around their respective colonies (Figure 1). The diameter of the inhibition zones around the antagonistic bacterial colonies E-45 and E-65 was $4 \pm 1.1 \mathrm{~mm}$ and $10 \pm 1.85 \mathrm{~mm}$ in triplicates in vitro experiments indicating stronger antagonistic actions of E-45 against the soft rot potato bacterium Ecc P-138 than that of E-45. Therefore, the isolate E-65 was selected for the control trial of storage potatoes against the most common soft rot bacterial strain Ecc P-138.

3.3. The Effect of Antagonistic Bacterial Strain E-65 on Storage Potato Tubers. The incidence of the soft rot bacterial infection to the potato tubers of different varieties at different time of intervals is shown in Figure 2. The infection started from the second week or later from the inoculation of soft rot bacterium Ecc P-138 and treatment with antagonistic bacterium (E-65). In the Cardinal and Diamant varieties, the infection was recorded at the second week, but, in the Granola variety, no infection was observed within the same period. After 22 weeks of storage, all varieties were infected. However, the highest infection $(62.5 \%)$ was observed in Cardinal variety and the lowest rate of infection (29.4\%) was found in the Granola variety. The Diamant variety demonstrated $38.2 \%$ infection after 22 weeks. On the other hand, the control group or E-65 untreated potatoes of all varieties incurred $100 \%$ damages within 22 weeks of the experimental time (Figure 2).

The effects of antagonistic bacteria on the weight loss (\% $\mathrm{w} / \mathrm{w}$ ) of potato tubers due to soft rot infection are shown in Figure 3. At the 22nd week of storage, the weight loss due to soft rot infection ranged $37.5-67.3 \%$ in different varieties under antagonistic bacteria treatment, while, in control group the loss was $100 \%$. The lowest loss was recorded in the variety Granola (37.5\%) and highest in Cardinal $(67.3 \%)$. The weight losses were always higher in control group. The highest reduction of disease due to treatment with antagonistic bacteria was found in Granola (62.5\%), and the lowest was observed in Cardinal $(32.7 \%)$ varieties (Figure 4). Thus, the Granola variety performed the best against the soft rot strain Ecc P-138 which was followed by Diamant and Cardinal.

3.4. Characterization and Identification of Two Antagonistic Bacterial Isolates. Two antagonistic bacterial isolates were Gram-positive and -negative in catalase, potato soft rot, and oxidase tests. The isolate E- 45 grew weakly in both at $37^{\circ} \mathrm{C}$ and $6.5 \% \mathrm{NaCl}$. The isolate $\mathrm{E}-65$ grew well in $6.5 \% \mathrm{NaCl}$ but weakly at $37^{\circ} \mathrm{C}$. In nitrate reduction test, isolate $\mathrm{E}$ 65 showed weak positive reaction with the development of orange-brown color, but isolate E- 45 showed clear positive reaction. Two isolates showed negative reaction in arginine utilization test. No gas formation was found in case of isolate E-65. Two isolates were negative in production of fluorescent pigment on King's B medium and tobacco hypersensitivity test (Table 4 Supplementary Information).

Isolate E-65 did not utilize cellobiose, lactose, maltose, L-arabinose, D-galactose, D-xylose, raffinose, sucrose, and 


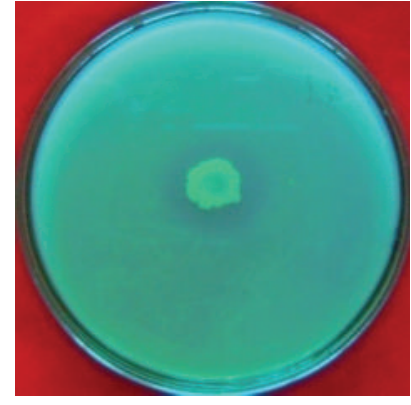

(a)

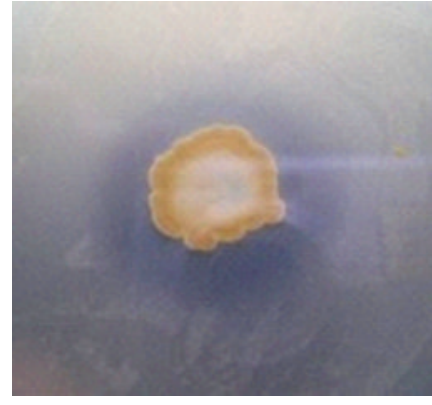

(b)

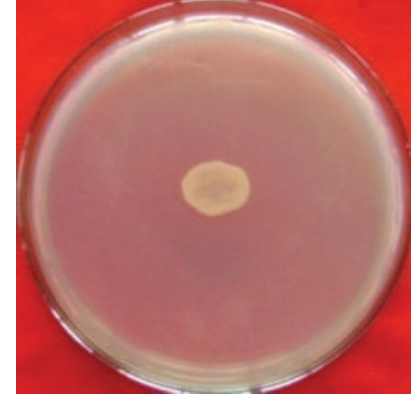

(c)

Figure 1: Antagonistic activity of isolates E-65 showing inhibition zones against potato soft rot bacterial strain Ecc P-138. (a) and (b) are representatives of positive inhibition as shown by the encircled inhibition zones, and (c) is presenting negative inhibition as demonstrated by the no-inhibition zone.

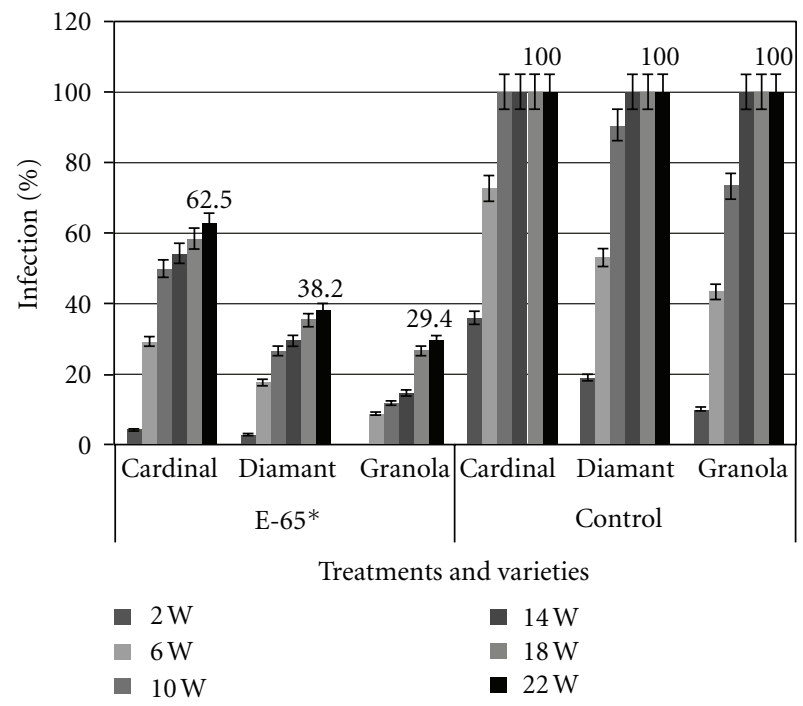

Figure 2: Effect of antagonistic bacteria* (E-65) on soft rot incidence of potato in storage as observed at an interval of 4 weeks (W).

trehalose but was positive in benzoate and D-tartrate. While the isolate E-45 utilized cellobiose, maltose, L-arabinose, Dgalactose, $\mathrm{D}$-xylose, raffinose, and sucrose but was negative in lactose, benzoate, and D-tartrate (Tables 5 and 6 Supplementary Information).

On the basis of the above physiological, biochemical, and carbon sources utilization test results, the antagonistic bacterial strain E-65 was identified as a member of the genus Bacillus and the isolate E-45 was a member of Lactobacillus sp. However, comprehensive molecular identification is necessary for assignment of the exact species of the isolated strains.

\section{Discussion}

The results of the present study demonstrated that the identified antagonistic bacterial strain E-65 can significantly inhibit the growth of soft rot bacteria in vitro and in storage. The pretreatment of potato tubers with antagonistic bacteria

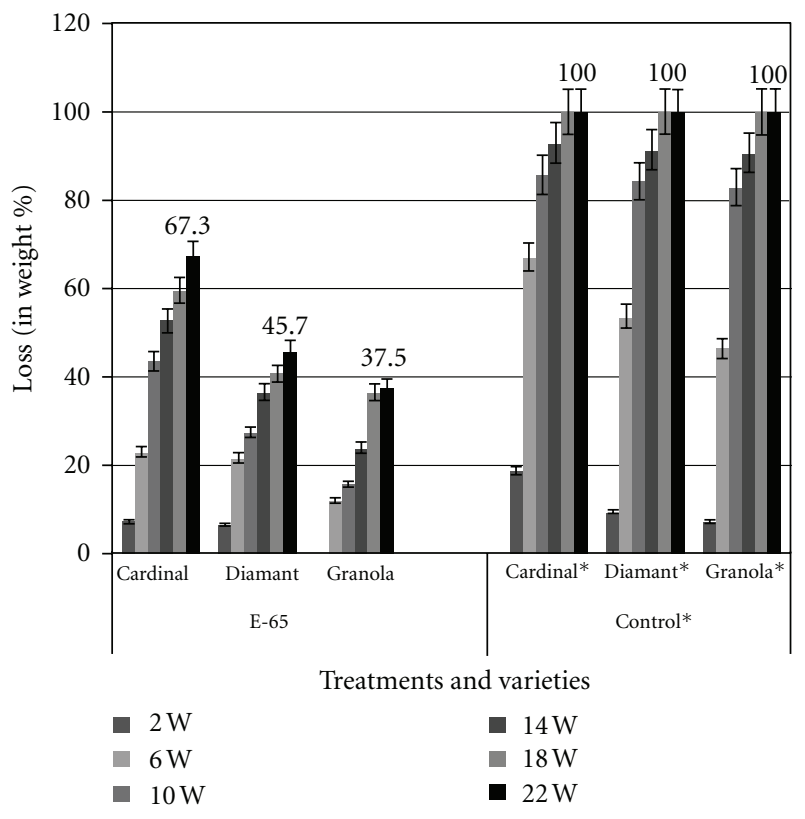

Figure 3: Effect of antagonistic bacteria (E-65) on weight loss (\% $\mathrm{w} / \mathrm{w}$ ) of three potato varieties under storage conditions.

successfully prevented the initial infection and reduce soft rot disease of potato and multiplication of soft rot bacteria. Earlier studies reported that antagonistic endophytic and rhizospheric bacteria have significant antagonistic activity against plant pathogenic bacteria including soft rot Erwinia genera [13, 29-32]. Long et al. [29] reported that the genus Bacillus and fluorescent pseudomonads have antagonistic activity against various plant pathogenic bacteria including soft rot bacterium E. carotovora subsp. carotovora (Ecc) in vitro. The ability of these isolates to suppress the growth of various phytopathogenic bacteria makes them potential biocontrol agents.

In the present study, biochemical and physiological identification methods suggested that identified antagonistic bacterial strain was Bacillus sp. and demonstrated strong antagonistic actions against the soft rot bacterial pathogen 


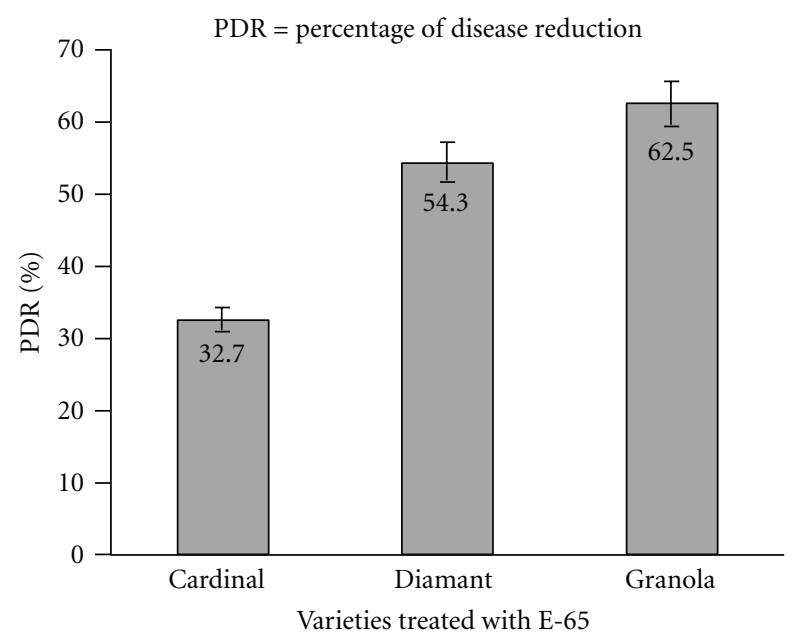

PDR at $22 \mathrm{~W}$

FIgURE 4: Effect of antagonistic bacteria (E-65) on the percentage of soft rot disease reduction (PDR) of potato at 22 weeks (W) of storage.

Ecc P-138 which was previously identified in our lab as the most virulent strain of Erwinia carotovora subsp. carotovora both in in vitro and under storage conditions. Many researchers previously exploited Bacillus sp. to control soft rot bacteria in various plants $[13,30-32]$. The results of the present experimental findings strongly correlated with those of the earlier findings $[13,30,32]$. Thus, the pretreatment of potato tubers with the identified biocontrol-agents can retard the initial infection of soft rot disease and inhibit the multiplication of soft rot pathogen. However, the present study was performed with $700 \mathrm{~g}$ potato tubers which are not sufficient to recommend its application for the large-scale storage of the potato tubers. The efficacy of the antagonistic bacteria needs to be tested using large amount of tubers before recommendation.

\section{Conclusion}

Two antagonistic bacterial isolates E-65 and E-45 of the common soft rot bacterial pathogen were isolated from the endophytes of potato and papaya of Bangladesh. The isolate E-65 was a strong antagonist of soft rot bacteria E. carotovora subsp. carotovora P-138. This was confirmed through the in vitro and storage experiments. Biochemical and physiological tests identified E-65 as a Bacillus sp. and E-45 as a Lactobacillus sp. The ability of these isolates to suppress the growth of various phytopathogenic bacteria makes them potential biocontrol agents.

\section{Acknowledgments}

This research is supported by the Ministry of Science and Information and Communication Technology of Bangladesh, and the publication cost was by the Universiti Malaya.

\section{References}

[1] R. Czajkowski, M. C. M. Perombelon, J. A. van Veen, and J. M. van der Wolf, "Control of blackleg and tubersoft rot of potato caused by Pectobacterium and Dickeya species: a review," Plant Pathology, vol. 10, pp. 1365-3059, 2011.

[2] G. N. Agrios, "Control of plant diseases," in Plant Pathology, pp. 200-216, Academic Press, San Diego, Calif, USA, 4th edition, 1997.

[3] G. W. Xu and D. C. Gross, "Selection of fluorescent pseudomonads antagonistic to Erwinia carotovora and suppressive of potato seed piece decay," Phytopathology, vol. 76, pp. 414422, 1986.

[4] N. Y. Abdelghafar and W. M. Abdelsayed, "Biological control of bacterial soft rot of potato by using flurescent pseudomonads," Arab Universities Journal Agricultural Science, vol. 5, no. 2, pp. 419-431, 1997.

[5] A. V. Sturz and B. G. Matheson, "Populations of endophytic bacteria which influence host-resistance to Erwinia-induced bacterial soft rot in potato tubers," Plant and Soil, vol. 184, no. 2, pp. 265-271, 1996.

[6] J. W. Kloepper, M. N. Schroth, and T. D. Miller, "Effects of rizosphere colonization by plant growth promoting rhizobacteria on potato plant development and yield," Phytopathology, vol. 70, pp. 1078-1082, 1980.

[7] J. W. Kloepper and M. N. Schroth, "Relationship of in vitro antibiosis of plant growth promoting rhizobacteria to plant growth and the displacement of root microflora," Phytopathology, vol. 71, pp. 1020-1024, 1981.

[8] J. E. Lopper, T. V. Suslow, and M. N. Schroth, "Lognormal distribution of bacterial populations in the rhizosphere," Phytopathology, vol. 74, pp. 1454-1460, 1984.

[9] H. R. Azad, J. R. Davis, W. C. Schnathorst, and C. I. Kado, "Relationships between rhizoplane and rhizosphere bacteria and verticillium wilt resistance in potato," Archives of Microbiology, vol. 140, no. 4, pp. 347-351, 1985.

[10] T. J. Burr and A. Caesar, "Beneficial plant bacteria," CRC Critical Review Plant Science, vol. 2, pp. 1-20, 1984.

[11] T. V. Suslow, "Role of root colonizing bacteria in plant growth," in Phytopathogenic Prokaryotes, M. S. Mount and G. H. Lacy, Eds., vol. 1, p. 541, Academic Press, New York, NY, USA, 1982.

[12] J. W. Kloepper, J. Leong, M. Teintze, and M. N. Schroth, "Enhanced plant growth by siderophores produced by plant growth-promoting rhizobacteria," Nature, vol. 286, no. 5776, pp. 885-886, 1980.

[13] H. Abd-El-Khair and H. E. H. Karima, "Application of some bactericides and bioagents for controlling the soft rot disease in potato," Research Journal Agricultural Biological Science, vol. 3, no. 5, pp. 463-473, 2007.

[14] D. Y. Kobayashi and J. D. Palumbo, "Bacterial endophytes and their effects on plants and uses in agriculture," in Microbial Endophyies, C. W. Bacon and J. F. White, Eds., pp. 99-233, Marcel Dekker, New York, NY, USA, 2000.

[15] S. Wakimoto, K. Hirayae, K. Tsuchiya, Y. Kushima, N. Furuya, and N. Matsuyama, "Production of antibiotics by plant pathogenic pseudomonads," Annual Phytopathology Soceity of Japan, vol. 52, pp. 835-842, 1986.

[16] N. Furuya, S. Yamasaki, M. Nishioka, I. Shirasshi, K. Ityama, and N. Matsuyama, "Antibacterial activities of pseudomonads against plantpathogenic organisms and efficacy of Pseudomonas aeruginosa ATCC7700 against bacterial wilt of tomato," Annual Phytopathology Soceity of Japan, vol. 63, pp. 417-424, 1997. 
[17] A. A. Hajhamed, W. M. A. E. Sayed, A. A. E. Yazied, and N. Y. A. E. Ghaffar, "Suppression of bacterial soft rot disease of potato," Egypt Journal Phytopathology, vol. 35, no. 2, pp. 6980, 2007.

[18] M. C. M. Pérombelon, J. Gullings-Handley, and A. Kelman, "Population dynamics of Erwinia carotovora and pectolytic clostridia in relation to decay of potatoes," Phytopathology, vol. 69, pp. 167-173, 1979.

[19] T. V. Suslow, M. N. Schroth, and M. Isaka, "Application of a rapid method for Gram differentiation of plant pathogenic and saprophytic bacteria without staining," Phytopathology, vol. 72, pp. 917-998, 1982.

[20] N. W. Schaad, "Initial identification of common genera," in Laboratory Guide for Identification of Plant Pathogenic Bacteria, N. W. Schaad, Ed., pp. 1-58, APS Press, St. Paul, Minn, USA, 2nd edition, 1988.

[21] D. N. Dye, "A taxonomic study of the genus Erwinia. 1. The amylovora group," New Zealand Journal Science, vol. 11, pp. 590-607, 1969.

[22] A. C. Hayward, "Identification of Pseudomonas solanacearum," In SAVERNET Bacterial Wilt Training Course held on October 5 to November 16 AVRDC. 101, 1992.

[23] N. Kovacs, "Identification of pseudomonas pyocyanea by the oxidase reaction," Nature, vol. 178, no. 4535, p. 703, 1956.

[24] M. J. Thornley, "The differentiation of P. solanacearum from other gram-negative bacteria on the basis of agrinine metabolism," Journal Applied Bacteriology, vol. 23, pp. 37-52, 1960.

[25] R. Hugh and E. Leifson, "The taxonomic significance of fermentative versus oxidative metabolism of carbohydrates by various gram negative bacteria," Journal of bacteriology, vol. 66, no. 1, pp. 24-26, 1953.

[26] T. Goszczynska, J. J. Serfontein, and Serfontein S., "Introduction to practical phytobacteriology. SAFRINET," The Southern African (SADC) Loop of BioNet-International, 2000.

[27] A. Klement and R. Goodman, "The hypersensitive reaction to infection by bacterial plant pathogens," Annual Review Phytopathology, vol. 5, pp. 17-44, 1967.

[28] S. H. Ayers, P. Rupp, and W. T. Johnson, "A study of the alkali forming bacteria in milk," University Seoul Department Agricultural Bulletin, pp.782, 1919.

[29] H. H. Long, N. Furuya, D. Kurose, M. Takeshita, and Y. Takanami, "Isolation of endophytic bacteria from Solanum sp. and their antibacterial activity against plant pathogenic bacteria," Journal of the Faculty of Agriculture, Kyushu University, vol. 48, no. 1-2, pp. 21-28, 2003.

[30] B. M. Sharga and G. D. Lyon, "Bacillus subtilis BS 107 as an antagonist of potato blackleg and soft rot bacteria," Canadian Journal of Microbiology, vol. 44, no. 8, pp. 777-783, 1998.

[31] F. Cladera-Olivera, G. R. Caron, A. S. Motta, A. A. Souto, and A. Brandelli, "Bacteriocin-like substance inhibits potato soft rot caused by Erwinia carotovora," Canadian Journal of Microbiology, vol. 52, no. 6, pp. 533-539, 2006.

[32] M. R. B. Raju, P. Vijai, and I. Jalali, "Antagonistic rhizospheric bacteria for management of bacterial soft rot of radish seed crop," Annual Plant Protection Science, India, vol. 14, no. 2, pp. 393-395, 2006. 

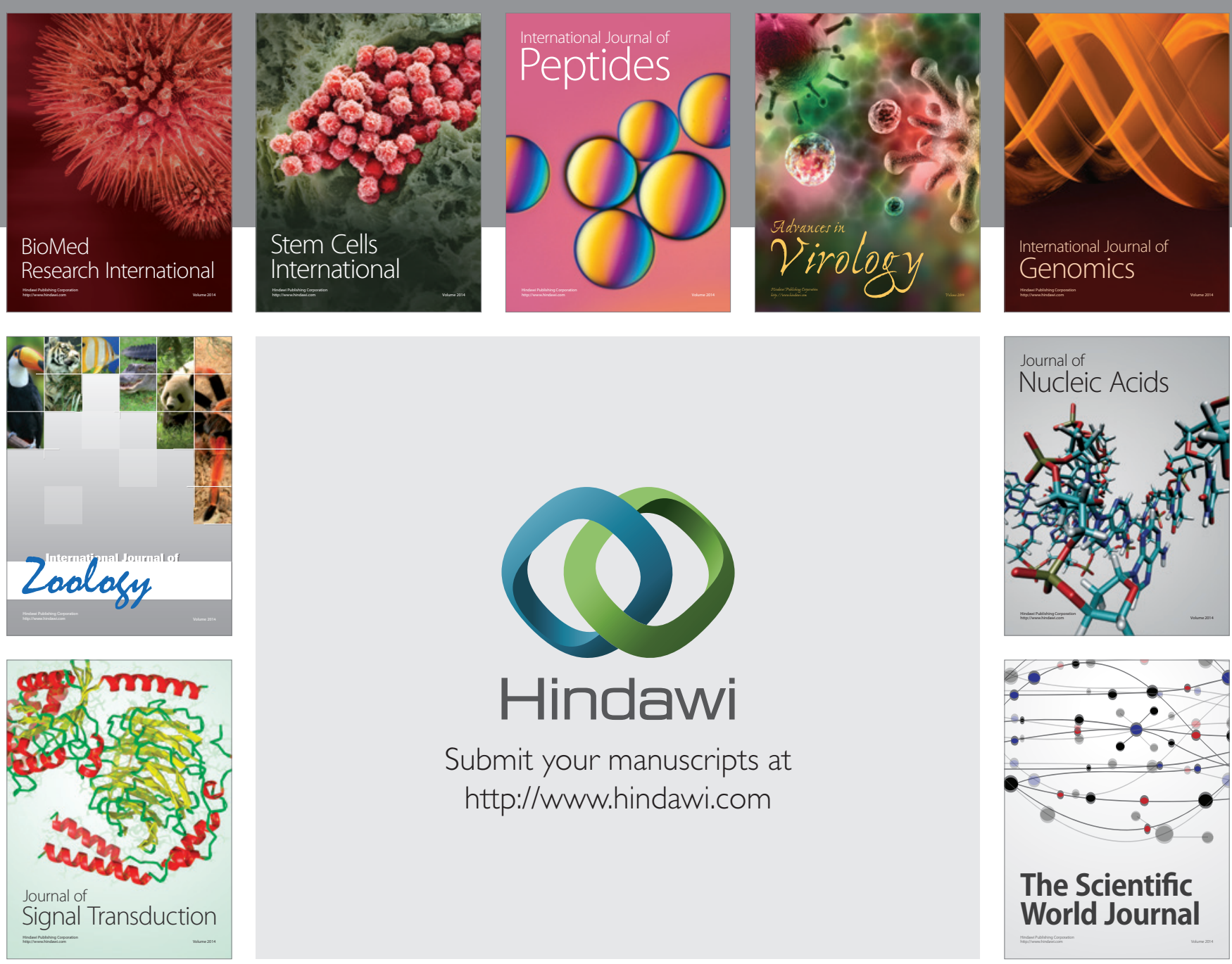

Submit your manuscripts at

http://www.hindawi.com
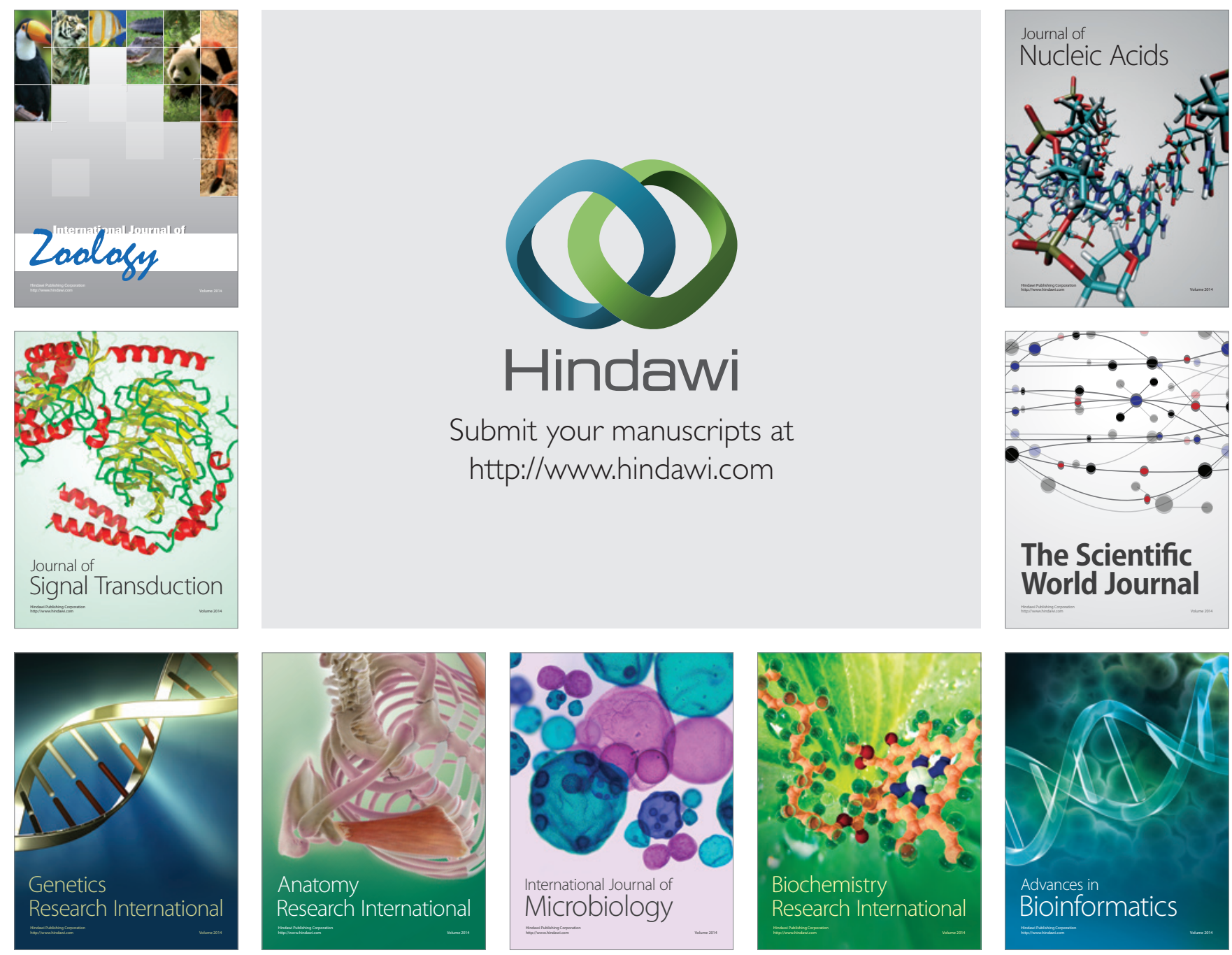

The Scientific World Journal
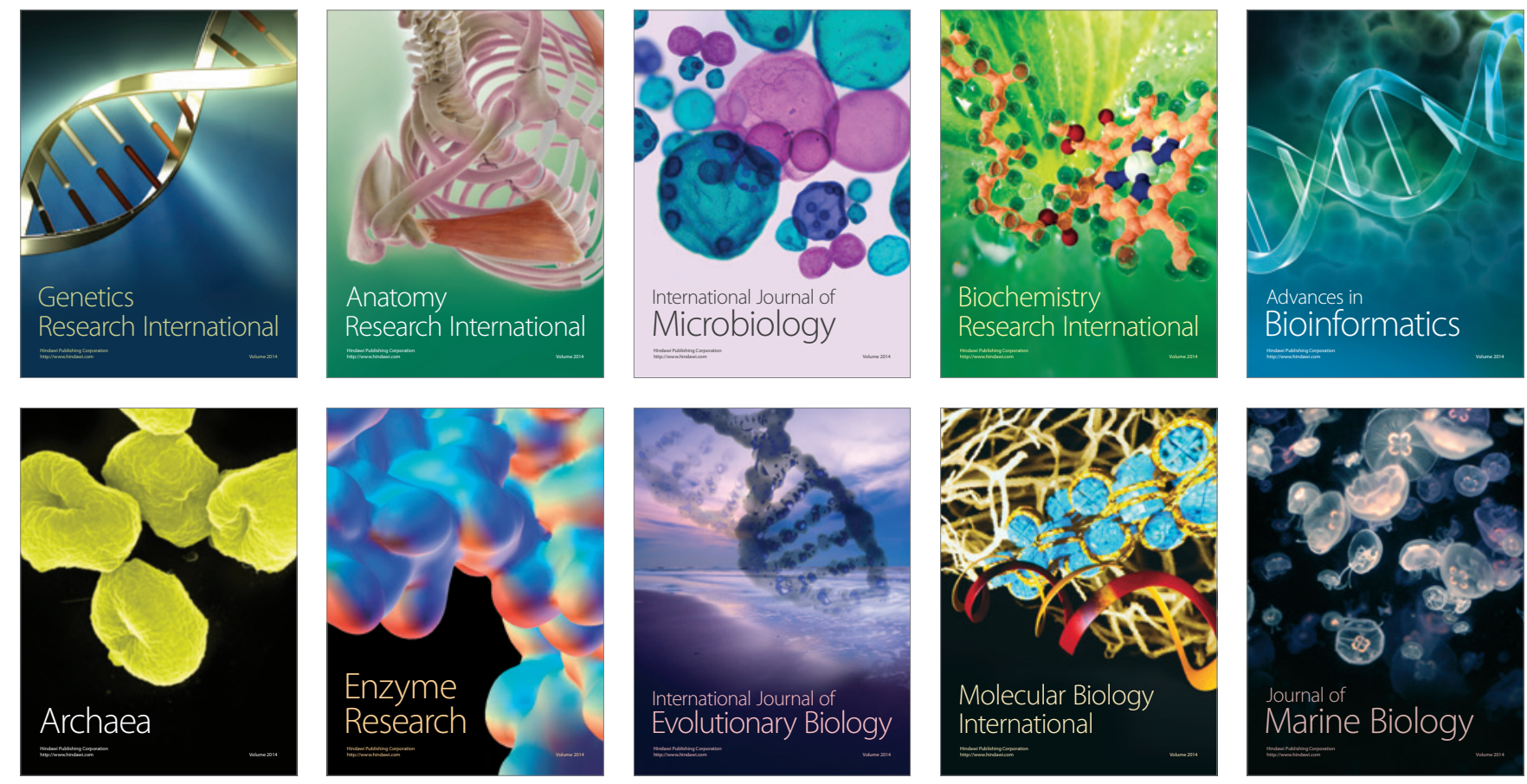